\title{
HUBUNGAN KADAR KOLESTEROL TOTAL DAN KARAKTERSITIK LANSIA TERHADAP FUNGSI EKSEKUTIF OTAK DI POSBINDU (POS BINAAN TERPADU) RW 02 KOTA DEPOK
}

\author{
Margreth Abletara Banurea ${ }^{1}$, Sugeng Wiyono ${ }^{2}$, Ria Maria Theresa ${ }^{1}$ \\ ${ }^{1}$ Faculty of Medicine, Universitas Pembangunan Veteran \\ ${ }^{2}$ Nutrition Department, Health Polytechnic-Ministry of Health Jakarta II
}

\begin{abstract}
ABSTRAK
Penurunan fungsi eksekutif terjadi pada hampir semua lansia yang disebabkan oleh perubahan biologis yang dialaminya dan umumnya berhubungan dengan proses penuaan. Tetapi penurunan fungsi eksekutif juga bisa terjadi karena kurangnya oksigenasi jaringan ke otak menyebabkan terjadi kerusakan neuron sehingga merubah struktur dan fungsi otak yang diakibatkan adanya sumbatan karena kelebihan kolesterol. Penelitian ini bertujuan untuk mengetahui Hubungan kolesterol total terhadap fungsi eksekutif lansia di Posbindu Lansia RW 02 Kota Depok. Penelitian ini merupakan studi analitik, menggunakan cross sectional. Penelitian ini dilakukan di Posbindu Lansia RW 02 Kota Depok. Sampel adalah lansia berusia 60 tahun keatas dan memiliki status pendidikan minimal SD serta tidak mengalami gangguan pendengaran yang datang ke Posbindu Lansia RW 02 Kota Depok. Teknik pengambilan sampel yang digunakan yaitu non probability sampling dengan metode purposive sehingga didapatkan 102 orang. Instrumen yang digunakan ialah Trail-Making Test $B$. Hasil uji Chi-Square menunjukkan bahwa terdapat hubungan yang bermakna antara tingkat pendidikan dan tingkat usia terhadap fungsi eksekutif pada lansia $(p=0,026$ dan $p=0,001)$. Untuk kolesterol total dan jenis kelamin, tidak dijumpai adanya hubungan dengan fungsi eksekutif lansia $(p=0,165, p=0,217)$.
\end{abstract}

Kata kunci: kolesterol, fungsi eksekutif, lansia

\section{ABSTRACT}

\section{THE RELATIONSHIP BETWEEN TOTAL CHOLESTEROL LEVEL AND CHARACTERISTICS OF ELDERLY TO THE BRAIN EXECUTIVE FUNCTIONS AT POSBINDU (POS BINAAN TERPADU) RW 02 DEPOK CITY}

In the normal process of aging, human will loose neuron cells every day. The lost would affect many brain functions. One of them is cognitive function, especially to its executive function. The effect happens to almost everyone and is caused by the biological changes in their bodies during the aging process. However, it may also be caused by the lack of oxygenation or oxygen perfusion to the brain tissue, which is caused by high levels of cholesterol that may create a blockage in the blood vessel and would, in turn, cause neuron demage, change brain structure and function. The objectives of this research were to discover the correlation of the total cholesterol levels and characteristics sampel to the executive function of the elderly at Posbindu lansia RW 02 Kota Depok. This research was an analytical study of cross sectional (with 95\% confidence level) done at Posbindu lansia RW 02 Kota Depok. The samples are elderly aged 60 years or more, they had educational status at least elementry school, they did not have hearing problem, and must attend the activity at Posbindu RW 02 Depok City when the study done. The sampling was purposive, and 102 subjects recruited. The instrument used in this research was Trail Making Test-B. The results of chi-square test showed that there were no correlations between total cholesterol levels and sex to their executive functions of elderly. However, between age group and educational level to brain executive functions indicated significant differences $(p=0,026$ dan $p=0,001)$.

Keywords: cholesterol, executive function, elderly

\section{PENDAHULUAN}

$\mathrm{S}$

alah satu indikator keberhasilan pembangunan adalah semakin meningkatnya usia harapan hidup penduduk. Semakin meningkat usia harapan hidup penduduk, maka menyebabkan jumlah penduduk lanjut usia terus meningkat dari tahun ke tahun. Berdasarkan hasil data sensus penduduk di Indonesia tahun 1980 jumlah 
penduduk lansia baru berjumlah 7,7 juta jiwa atau 5,2 persen dari jumlah seluruh penduduk. Pada tahun 1990 jumlah penduduk usia lanjut terjadi peningkatan menjadi 11,28 juta jiwa atau 8,9 persen, jumlah ini meningkat di seluruh Indonesia sehingga pada tahun 2005 jumlah penduduk usia lanjut ditemukan sebesar 17,7 juta jiwa atau 7,97 persen dari seluruh penduduk dan diperkirakan tahun 2020 jumlah usia lanjut diperkirakan akan meningkat menjadi 28,8 juta. ${ }^{1}$

Menurut Depkes RI (1999), lansia atau lanjut usia adalah seseorang yang berusia 60 tahun ke atas. ${ }^{2}$ Terdapat tiga aspek yang perlu dipertimbangkan, yaitu aspek biologi, aspek ekonomi dan aspek sosial. ${ }^{3}$ Secara biologis penduduk lanjut usia adalah penduduk yang mengalami proses penuaan secara terus menerus, yang ditandai dengan menurunnya daya tahan fisik yaitu semakin rentannya terhadap serangan penyakit yang dapat menyebabkan kematian. Hal ini disebabkan terjadinya perubahan dalam struktur dan fungsi sel, jaringan, serta sistem organ. Sedangkan secara ekonomi, penduduk lanjut usia lebih dipandang sebagai beban daripada sebagai sumber daya. Banyak orang beranggapan bahwa kehidupan masa tua tidak lagi memberikan banyak manfaat, bahkan ada yang sampai beranggapan bahwa kehidupan masa tua, seringkali dipersepsikan secara negatif sebagai beban keluarga dan masyarakat yang pada akhirnya dapat mempengaruhi keadaan psikis lansia. Dilihat dari aspek sosial, penduduk lanjut usia merupakan satu kelompok sosial tersendiri.

Menurut Joseph J. Gallo (1998), gangguan kesehatan fisik pada lanjut usia harus dipertimbangkan seperti menurunnya pendengaran, penglihatan, gerakan yang terbatas, dan waktu respon yang lamban. ${ }^{4}$ Menurunnya kondisi psikis ditandai dengan menurunnya fungsi kognitif. ${ }^{5}$ Penurunan fungsi kognitif meliputi gangguan proses belajar, persepsi pemahaman, pengertian, perhatian, dan lain-lain yang menyebabkan reaksi dan perilaku lanjut usia menjadi semakin lambat.

Fungsi kognitif adalah kemampuan seseorang untuk menerima, mengolah, menyimpan, menggunakan kembali semua masukan sensorik secara baik. Fungsi kognitif terdiri atas unsur perhatian (attention), mengingat (memory), bahasa (communication), bergerak (motorik), dan fungsi eksekutif (executive function). Fungsi eksekutif adalah serangkaian proses kognitif yang mendukung perencanaan, inisiasi dan pelaksanaan perilaku tujuan termasuk fleksibilitas mental dan pemecahan masalah. ${ }^{6}$ Fungsi kognitif dan fungsi eksekutif tersebut diatur oleh otak terutama pada lobus frontal. Fungsi otak tergantung suplai oksigen dan glukosa secara kontinu sebagai sumber energi dan gizi bagi otak guna memelihara bermilyar sel otak dengan baik. Tingginya risiko disfungsi vaskular pada pasien hiperkolesterolemia diyakini sebagai penyebab menurunnya fungsi eksekutif otak. $^{7}$

Hiperkolesterolemia merupakan suatu keadaan terjadi peningkatan kadar kolesterol di dalam darah. Hiperkolesterolemia menyebabkan aterosklerosis (penyumbatan) arteri serebral yang akan menyebabkan terganggunya sirkulasi darah ke otak sehingga asupan oksigen dan gizi di dalam otak berkurang. Selanjutnya akan mengalami iskemi sampai dengan infark yang akan lama-kelamaan menyebabkan kerusakan neuron, struktur dan fungsi otak. Dimana salah satunya dapat menyebabkan penurunan fungsi eksekutif otak. ${ }^{8}$

Berdasarkan latar belakang permasalahan yang telah diuraikan di atas studi ini akan melihat hubungan antara kadar kolesterol total dalam darah dengan fungsi eksekutif pada lansia. Sehingga permasalahan penelitian dapat dirumuskan sebagai berikut Apakah ada hubungan kadar kolesterol total terhadap fungsi eksekutif pada lansia di Posbindu RW 02 Kota Depok.

Tujuan Umum penelitian adalah mengetahui hubungan antara kolesterol total dengan fungsi eksekutif lansia. Sedangkan sebagai tujuan khusus adalah: 1). Memperoleh gambaran fungsi eksekutif lansia di Posbindu RW 02 Kota Depok, 2). Memperoleh gambaran kolesterol total lansia di Posbindu RW 02 Kota Depok, 3). Memperoleh gambaran usia lansia di Posbindu RW 02 Kota Depok, 4). Memperoleh gambaran tingkat pendidikan lansia di Posbindu RW 02 Kota Depok, 5). Memperoleh gambaran jenis kelamin lansia di Posbindu RW 02 Kota Depok. 6). Mengetahui hubungan status kolesterol total dengan fungsi eksekutif lansia, 7). Mengetahui hubungan usia dengan fungsi eksekutif pada lansia di Posbindu RW 02 Kota 
Depok. 8). Mengetahui hubungan tingkat pendidikan dengan fungsi eksekutif pada lansia di Posbindu RW 02 Kota Depok, 9). Mengetahui hubungan jenis kelamin dengan fungsi eksekutif pada lansia di Posbindu RW 02 Kota Depok.

\section{METODE PENELITIAN}

Penelitian ini dilakukan di Pos Pembinaan Terpadu (Posbindu) di RW 02 Kota Depok yang berlokasi di Jalan Mangga Raya No. 88 A Depok Jaya. Jenis penelitian ini adalah survey analitik dengan menggunakan pendekatan survey cross sectional. Populasi penelitian ini adalah semua lanjut usia (lansia) yang berada di RW 02 kota Depok dengan populasi berjumlah 320 orang. Sampel diambil dari jumlah lansia yang datang ke Posbindu Lansia RW 02 Kota Depok yang memenuhi kriteria inklusi dan eksklusi: 1). Pria dan wanita, 2). Usia $\geq 60$ tahun, 3). Lanjut usia yang datang ke Posbindu RW 02 kota Depok, 4). Pendidikan minimal SMP., 5). Bersedia diikutsertakan menjadi responden dalam penelitian. Sedangkan sebagai krirteria eksklusi adalah: 1). Penderita afasia berat, 2). Penderita stroke atau mempunyai riwayat stroke, 3). Penderita Demensia. 4). Penderita Parkinson, 5). Tuna aksara, 6). Tidak bersedia diikutsertakan menjadi responden dalam penelitian

Teknik pengambilan sampel yang digunakan dalam penelitian ini adalah Non Probability Sampling dengan metode sampling jenuh, yaitu teknik penarikan sampel dengan mengambil seluruh lanjut usia yang datang ke Posbindu RW 02 Kota Depok pada saat penelitian. Dengan mempertimbangkan kriteria tersebut diperoleh sampel sejumlah 102 orang.

Data yang akan dikumpulkan terdiri dari data primer. Data primer meliputi karakteristik responden meliputi: usia, jenis kelamin, tingkat pendidikan, pekerjaan, status pernikahan, status kesehatan (lama sakit, frekuensi sakit, keluhan kesehatan dan tindakan pengobatan) sebulan terakhir, fungsi eksekutif (berfikir, berencana), dan kadar kolesterol total. Data karakteristik responden mengenai status kesehatan dan fungsi eksekutif diperoleh melalui wawancara langsung dengan alat bantu kuesioner. Data status kesehatan diperoleh dengan penilaian subjektif berdasarkan hasil wawancara tanpa melakukan pemeriksaan klinis. Penilaian kadar kolesterol dilakukan dengan menggunakan alat cek kolesterol, sedangkan untuk menilai fungsi eksekutif diukur dengan menggunakan Trail Making Test- $B$ (TMT-B), dimana responden diminta untuk mengurutkan huruf dan juga angka yang dikombinasi dengan huruf Trail Making Test- $B$ (TMT-B). Tes ini memerlukan waktu sebagai standar untuk menilai fungsi eksekutif responden tersebut.

\section{Trail-Making Test- B}

Trail Making Test-B yaitu salah satu tes neuropsikologis yang paling sering digunakan dalam praktek klinis dan merupakan salah satu instrumen yang paling sensitif terhadap kerusakan otak terutama kemampuan visual dan beralih tugas. ${ }^{9}$ Pada Trail Making Test- $B$ terdapat lingkaran antara kedua angka (1-13) dan huruf $(A-L)$ dan pasien diinstruksikan harus menarik garis untuk menghubungkan lingkaran dalam pola ascending, tetapi dengan tambahan penarikan garis harus bergantian antara angka dan huruf (yaitu, 1-A-2-B-3-C, dII). Pasien harus diinstruksikan untuk menghubungkan lingkaran secepat mungkin, tanpa mengangkat pena atau pensil dari kertas. Ketika pasien sedang melakukan penarikan garis, jika pasien membuat kesalahan, pasien diinstruksikan untuk sesegera mungkin memperbaikinya. Tidak perlu terus uji jika pasien belum menyelesaikan kedua bagian setelah lima menit berlalu.

Penilaian hasil dilaporkan dalam satuan waktu (detik) yaitu lama waktu yang dibutuhkan pasien untuk menyelesaikan tugas, sehingga jika nilai yang dihasilkan lebih tinggi menunjukkan penurunan atau gangguan yang lebih besar, dengan nilai normal (75 second) dan terdapat gangguan fungsi eksekutif (>273 second). Selanjutanya dilakuan analisis univariat untuk melihat gambaran setiap variable dan analisis bivariat untuk menganalisis hubungan antara dua variabel yaitu variable bebas (independen). Untuk membuktikan hipotesis penelitian digunakan uji Chi-Square dengan alpha= 0,05.

\section{HASIL}

Analisis pada setiap variabel (analisis univariat) menunjukan bahwa sebanyak 11,8 persen termasuk kelompok lansia tua (berumur 
75-90 tahun). Untuk tingkat pendidikan menunjukkan bahwa sebagian besar $(73,5 \%)$ menyelesaikan pendidikan pada jenjang SD-SMP. Persentase antara lansia laki-laki dan lansia perempuan hampir seimbang yaitu laki-laki sebanyak 45,1 persen dan perempuan sebanyak 54,9 persen. Untuk status kolesterol total diperoleh sebesar 37,3 persen lansia dengan status kolesterol total tinggi. Sedangkan untuk fungsi eksekutuf diperoleh bahwa 51,9 persen lansia dengan fungsi eksekutif tidak normal. Untuk lebih jelas dapat dilihat pada Tabel 1 berikut:

Tabel 1

Karakteristik, Status Kolesterol dan Fungsi Eksekutif Responden

\begin{tabular}{lcc}
\hline Karakteristik & $\mathrm{n}(=102)$ & $\%$ \\
\hline Umur & & \\
1. Lansia muda (60-74 tahun) & 90 & 88,2 \\
2. Lansia tua (75-90 tahun) & 12 & 11,8 \\
Tingkat pendidikan & & \\
1. SD-SMP & 75 & 73,5 \\
2. SMA-PT & 27 & 26,5 \\
Jenis Kelamin & & \\
1. Laki- laki & 46 & 45,1 \\
2. Perempuan & 56 & 54,9 \\
Fungsi Eksekutif & & 48,1 \\
1. Normal & 49 & 51,9 \\
2. Tidak normal & 53 & 62,7 \\
Status Kolesterol Total & & 37,3 \\
1. Normal & 64 & \\
2. Tinggi & 38 & \\
\hline
\end{tabular}

Analisis selanjutnya untuk mengetahui kaitan antara fungsi eksekutif sebagai out-put dengan faktor risiko maka dilakukan analisis bivariat. Kaitan faktor risiko yang meliputi status kolesterol, usia, pendidikan dan jenis kelamin terlihat pada Tabel 2

Tabel 2 menunjukkan bahwa fungsi ekskutif tidak normal lebih besar pada kelompok lansia dengan status kolesterol total tinggi $(60,5 \%)$ dibanding dengan kelompk lansia pada status kolesterol total norml (46,9\%). Namun secara statistik tidak ada hubungan bermakna ( $\mathrm{p}=$ 0.160) antara kadar kolesterol total dengan fungsi eksekutif lansia.

Untuk usia terlihat bahwa fungsi ekskutif tidak normal lebin besar terdapat kelompok lansia muda $(46,8 \%)$ dibanding dengan kelompok lansia tua $(8,2 \%)$. Hasil tersebut diperkuat dengan hasil uji statistik yang menunjukkan bahwa ada hubungan bermakna $(p=0.001)$ antara usia dengan fungsi eksekutif.

Untuk tingkat pendidikan terlihat bahwa fungsi eksekutif tidak normal lebih besar pada kelompk lansia dengan tingkat pendidikan tinggi $(70,4 \%)$ dibanding dengan lansia pada pendidikan rendah $(45,3 \%)$. Hasil tersebut diperkuat dengan hasil uji statistik yang menyimpulkan bahwa ada hubungan bermakna $(p=0,026)$ antara tingkat pendidikan dengan fungsi eksekutif.

Sedangkan untuk jenis kelamin menunjukkan bahwa fungsi ekskutif tidak normal lebih banyak terjadi pada lansia laki-laki $(58,7 \%)$ dibanding dengna lansia perempuan $(46,4 \%)$. Namun demikian hasil uji statistik menunjukkan bahwa tidak terdapat hubungan bermakna $(p=0,217)$ antara jenis kelamin dan fungsi eksekutif. 
Tabel 2

Distribusi Faktor Risiko dan Fungsi Eksekutif Lansia di Posbindu RW 02 Depok

\begin{tabular}{|c|c|c|c|c|c|c|c|}
\hline \multirow[t]{2}{*}{ Faktor Risiko } & \multicolumn{2}{|c|}{$\begin{array}{l}\text { Normal } \\
(n=49)\end{array}$} & \multicolumn{2}{|c|}{$\begin{array}{l}\text { Fungsi Eksekutif } \\
\text { Tidak normal } \\
(n=53)\end{array}$} & \multicolumn{2}{|c|}{$\begin{array}{c}\text { Total } \\
(n=102)\end{array}$} & \multirow[t]{2}{*}{$p$ value } \\
\hline & $\mathrm{n}$ & $\%$ & $\mathrm{n}$ & $\%$ & $\mathrm{n}$ & $\%$ & \\
\hline \multicolumn{8}{|l|}{ Status Kolesterol } \\
\hline 1. Normal & 34 & 53,1 & 30 & 46,9 & 64 & 100,0 & \\
\hline 2. Tinggi & 15 & 39,5 & 23 & 60,5 & 38 & 100,0 & 0,165 \\
\hline \multicolumn{8}{|l|}{ Usia } \\
\hline $\begin{array}{l}\text { 1. Lansia muda } \\
\text { (60-74 tahun) }\end{array}$ & 38 & 43,2 & 52 & 46,8 & 90 & 100,0 & 0,001 \\
\hline $\begin{array}{l}\text { 2. Lansia tua } \\
\text { (75-90 tahun) }\end{array}$ & 11 & 91,7 & 1 & 8,2 & 12 & 100,0 & \\
\hline \multicolumn{8}{|l|}{ Pendidikan } \\
\hline 1. $S D-S M P$ & 41 & 54,7 & 34 & 45,3 & 75 & 100,0 & 0,026 \\
\hline 2. $S M A-P T$ & 8 & 29,6 & 19 & 70,4 & 27 & 100,0 & \\
\hline \multicolumn{8}{|l|}{ Jenis Kelamin } \\
\hline 1. Perempuan & 30 & 53,6 & 26 & 46,4 & 56 & 100,0 & 0,217 \\
\hline 2. Laki- laki & 19 & 41,3 & 27 & 58,7 & 46 & 100,0 & \\
\hline
\end{tabular}

\section{BAHASAN}

Hubungan kolesterol total darah dengan fungsi eksekutif

Berdasarkan hasil analisa bivariat, diperoleh nilai $p=0,165$ yang artinya tidak terdapat hubungan bermakna antara kolesterol total lansia dengan fungsi eksekutif. Hubungan antara kolesterol dengan fungsi kognitif telah banyak diteliti. Reitz, dkk (2004) melakukan studi terhadap 1147 lanjut usia yang sehat tanpa demensia ataupun gangguan kognitif, diperoleh hasil bahwa tidak ada hubungan yang bermakna antara kolesterol total, HDL dan LDL dengan gangguan fungsi kognitif. ${ }^{10}$

Salomon, dkk (2008) yang menemukan bahwa kadar kolesterol total yang tinggi pada usia pertengahan berhubungan dengan fungsi kognisi yang buruk pada usia lanjut namun tidak untuk subyek yang mendapatkan statin. ${ }^{11}$ Dalam penelitian ini penulis hanya melakukan pemeriksaan kolesterol total, tidak melakukan pemeriksaan kolesterol LDL. Moroney et al (1999) dalam penelitian prospective longitudinal community-based tentang LDL kolesterol dan risiko demensia, menyimpulkan bahwa peningkatan LDL kolesterol berhubungan dengan risiko demensia. ${ }^{8}$

\section{Hubungan usia dengan fungsi eksekutif}

Berdasarkan hasil analisa bivariat, diperoleh nilai $p=0,001$ artinya terdapat hubungan bermakna antara usia lansia dengan fungsi eksekutif. Hal ini sesuai dengan hasil penelitian Yaffe dkk (2002), sekitar 10,0 persen orang tua yang berusia lebih dari 65 tahun dan 50,0 persen pada usia yang lebih dari 85 tahun akan mengalami gangguan kognitif, dimana akan dijumpai gangguan yang ringan sampai terjadinya demensia. ${ }^{12}$ Hasil The 1st Symposium on Brain and Cognitif Function (2009), salah satu masalah yang sering ditemui pada golongan lansia akibat bertambahnya usia adalah gangguan kesehatan yang terkait erat dengan proses degeneratif yang tidak dapat dihindari. Seluruh sistem organ, cepat atau lambat, akan mengalami proses degenerasi termasuk otak. Salah satu manifestasi klinik yang khas dari degenerasi otak adalah timbulnya gangguan kognitif yang juga dapat merusak fungsi eksekutif otak. ${ }^{13}$

\section{Hubungan tingkat pendidikan dengan fungsi eksekutif \\ Berdasarkan hasil analisa bivariat, diperoleh nilai $p=0,026$ yang artinya terdapat hubungan bermakna antara usia lansia dengan}


fungsi eksekutif. Hasil penelitian ini sesuai dengan hasil penelitian MS Rizky (2011), bahwa tingkat pendidikan yang rendah berhubungan dengan penurunan fungsi kognitif yang dapat terjadi lebih cepat dibandingkan dengan tingkat pendidikan yang tinggi. ${ }^{14}$ Diduga ada beberapa mekanisme yang mendasari proses ini yaitu: a). Teori brain reverse, yang menjelaskan bahwa tingkat pendidikan dan penurunan fungsi kognitif karena usia saling berhubungan karena keduanya didasarkan pada potensi kognitif yang didapat sejak lahir. b). Teori "use it or lose it", menjelaskan bahwa stimulus mental selama dewasa merupakan proteksi dalam melawan penurunan fungsi kognitif yang prematur. Pendidikan pada awal kehidupan mempunyai pengaruh pada kehidupan selanjutnya jika seseorang tersebut terus melanjutkan pendidikan untuk menstimulasi mental yang diduga bermanfaat untuk neurokimia dan pengaruh struktur otak. Selanjutnya teori synaptic reserve hypothesis, menjelaskan bahwa orang yang berpendidikan tinggi mempunyai lebih banyak synaps di otak dibanding orang yang berpendidikan rendah. Teori ini berhubungan dengan cognitive reserve hypothesis dimana orang yang beredukasi memiliki lebih banyak sinaps pada otak dan mampu melakukan kompensasi lebih baik terhadap hilangnya suatu kemampuan dengan menggunakan strategi alternatife pada tes yang didapati selama pelatihan selama pendidikan.

\section{Hubungan jenis kelamin dengan fungsi eksekutif}

Hasil uji Chi-Square didapatkan $p=0,217$ artinya tidak terdapat hubungan bermakna antara jenis kelamin terhadap fungsi kognitif pada lansia. Hal ini tidak sesuai dengan (Myers, 2008), yang menyatakan bahwa perempuan tampaknya lebih beresiko mengalami penurunan kognitif. ${ }^{15} \mathrm{Hal}$ ini disebabkan adanya peranan level hormon seks endogen dalam perubahan fungsi kognitif. Reseptor estrogen telah ditemukan dalam area otak yang berperan dalam fungsi belajar dan memori, seperti hipokampus. Rendahnya level estradiol dalam tubuh telah dikaitkan dengan penurunan fungsi kognitif umum dan memori verbal. Estradiol diperkirakan bersifat neuroprotektif dan dapat membatasi kerusakan akibat stress oksidatif serta terlihat sebagai protektor sel saraf dari toksisitas amiloid.

\section{SIMPULAN}

Dari penelitian ini dapat disimpulkan bahwa sebesar $11,76 \%$ termasuk lansia tua, berumur $75-90$ tahun, sebesar $73,4 \%$ lansia berpendidikan SD-SMP, sebagian besar $(52,9 \%)$ lansia mengalami gangguan fungsi eksekutif, sebesar 37,3\% lansia memiliki status kadar kolesterol total tinggi. Hasil analisis bivariat menunjukkan bahwa ada hubungan bermakna $(p=0,001)$ antara usia dengan fungsi eksekutif lansia, ada hubungan bermakna $(p=0,026)$ antara tingkat pendidikan dengan fungsi eksekutif lansia, tidak ada hubungan bermakna $(p=0,165)$ antara status kolesterol total dengan fungsi eksekutif lansia, tidak ada hubungan bermakna $(p=0,217)$ antara jenis kelamin dengan fungsi eksekutif lansia

\section{RUJUKAN}

1. Badan Pusat Statistik. Statistics Indonesia. Jakarta: Badan Pusat Statistik; 1980.

2. Departemen Kesehatan RI. Rencana Pembangunan Kesehatan Menuju Indonesia Sehat 2010. Jakarta: Depkes; 1999.

3. Badan Koordinasi Keluarga Nasional. Pedoman Pengelolaan Bina Keluarga Lansia (BKL). Jakarta: Biro Ketahanan Non Fisik BKKBN; 1998.

4. Gallo, Joseph J. Buku Saku Gerontology Edisi 2. Jakarta: EGC; 1998.

5. Zainudin. Fungsi Kognitif Lansia. Thesis. Bogor: IPB; 2002.

6. Yaffe K, Haan M, Blackwell T, Cherkasova E, Whitmer RA, West N. Metabolic Syndrome and Cognitif Decline in Elderly Latinos: findings from the sacramento are latino study of aging study. 2007. J Am Geriatr Soc. 2007; 55(5): 758-62.

7. Husada, J. Acute Ischemic Stroke. Role of neuropeptides in Neuroprotection. Stroke in Depth Now and Future. Surabaya: FK Airlangga; 2004.

8. Moroney, J. T., Tang M. X., Small S., Merchant C., Bell K., Stern Y., Maeyeux R. Low Density Lipoprptein Cholesterol and the Risk of Dementia With Sroke, New York, JAMA. 1999; 282(254-60)

9. Rabin, L.A., Barr, W.B., \& Burton, L.A. 
Assessment practices of clinical neuropsychologists in the United States and Canada: a survey of INS, NAN, and APA Division 40 members. Archives of Clinical Neuropsychology. 2005; 20: 33-65.

10. Reitz, C., Toeng, M.X., Luchsinger, J., Mayen, X. Relation of Plasma Lipid \& Alzheimer Disease and Vascular Dementia. Arch Neurol. 2004; 61: 705

11. Salomon, dkk. Kognitif kontrol dalam gangguan spektrum autism. International Journal of Developmental Neuroscience. 2008; 26(2): 239-247.
12. Yaffe $K$, Lui L-Y, Zmuda J, Cauley J. Sex hormones and cognitive function in older men. 2002. J Am Geriatrics Soc;50:707-12

13. The 1st Symposium on Brain and Cognitif Function. 2009. Menggali Persoalan Kompleks Gangguan Kognitif. Jakarta, 2009.

14. MS Rizky, 2011, Hubungan Tingkat Pendidikan dan Aktivitas Fisik Dengan Fungsi Kognitif Pada Lansia.

15. Myers, J.S. 2008. Factors Associated with Changing Cognitive Function in Older. c2008. Available from: www.rehabnurse.org/pdf/mj285.pdf 